Original Research Paper

\title{
The Exchange Rate Pass-Through into Inflation with Symmetric Oil Price Shocks: An Empirical Analysis for Saudi Arabia: 1970-2015
}

\author{
Abdulaziz Hamad Algaeed \\ Department of Finance and Banking, College of Business Administration, \\ Dar Al Uloom University. Riyadh, Saudi Arabia. P. O. Box 87757, Riyadh 11652. Saudi Arabia
}

Article history

Received: 17-11-2017

Revised: 02-01-2018

Accepted: 24-01-2018

Email: ibngaeed@outlook.com

\begin{abstract}
The purpose of this paper is to analyze theoretically and empirically the relationship between inflation as a dependent variable and bilateral exchange rate, output gap and symmetric oil price shocks. The ARDL methodology is employed considering the period of 1970-2015. The exchange rate pass-through to inflation will be thoroughly investigated. Johansen's testing procedure confirms the existence of longrun relationships between consumer price inflation, exchange rate, symmetric oil price changes and output gap as a proxy for aggregate demand. The estimation results reveal that depreciation of the exchange rate and the symmetric oil price shocks are main factors responsible for long-run domestic consumer price inflation in Saudi Arabia. Although the output gap as a proxy for aggregate demand had the right sign but its contribution is little in explaining the variations in domestic inflation in the long-run. This could be attributed to the sufficient Saudi economic capacity. In economic literature, the findings here are in line and consistent with other researchers' estimation results.
\end{abstract}

Keywords: Saudi Arabia, Exchange Rate, Inflation, ARDL, Pass-through

\section{Introduction}

Nowadays, there has been resurgence of attention to the issue of the channels through which inflation is aggravated. The topic of exchange rate and its relation with inflation is not a new in economic literature. The importance of the exchange rate effects stems from the fact that in the case of a small country, the domestic price of the traded goods is the world's price traded goods adjusted for the exchange rate. This is called Purchasing Power Parity (PPP). As can be seen, the variations in the exchange rate will have an effect on price of non-traded goods. The appreciation of exchange rate is attributed to the rise of prices of non-tradable goods due to the increase of production cost. Furthermore, the fall in aggregate demand is caused by the declining purchasing power as a result of an increase in oil prices. On the whole, exchange rate divergences will affect social prices of goods and cost production (Omoniyi and Olawale, 2015). Saudi Arabia has blessed with years of oil revenues accumulated over time. The oil producing countries like the kingdom, share the same characteristics of other less developed countries. The large participation of the public sector is a distinguishing feature of these economies. The huge dominance of the public sector is due to the fact that private sector is small and weak. Other several features give the Saudi economy a special position with respect to the rest of the world. Equally important, these features are the economic structure, the non-oil sector and the foreign sector. The last 40 years or so of oil fluctuations have affected the exchange rate via the aggressive government plans and expenditure. According to Edwards (1989) there are two channels, besides the government spending, that affect exchange rate. Higher commodity prices (oil price increase) will lead to an increase in foreign exchange earnings. This increase in foreign exchange earnings will be transmitted into a rise in domestic money supply and hence, coupled with an increase in inflation. In like manner, appreciation of local currency (Riyal) will occur either in the rise in nominal exchange rate or in the rise of non-traded goods prices, given nominal exchange rate. The third channel assumes negative relationship between the price of booming commodity (Oil) and exchange rate 
Edwards (1989). This assumption is not conclusive and subject to empirical investigations. After 1971 Saudi Arabia has pegged its currency to the US dollar. The rationale behind this is that, oil revenue denominated in dollars, which make it easy for monetary authorities to plan the budget and the pegging in this case helps stabilizing price of imports. In addition, most of Saudi investments are in the US and denominated in dollars too. The period between 1975 and 1981, Saudi government pegged the Riyal to SDR. Despite the arguments between economists concerning pegging to a basket of currencies, who favors the basket asserts that variations in exchange rate will be minimal and hence, price of imports and inflation are controlled. Likewise, the depreciation of the euro has posed price instability in the euro areas. This issue encouraged researchers to study its impacts on the consumer prices. Hüfner and Schröder (2002), Cheikh and Rault (2015), Comunale and Kunovac (2017) and Mirdala (2014). Based on McCarthy (2000), pass-through of exchange rate, symmetric oil price shock, adaptive expectations and output gap to inflation are implemented. The choice of symmetric oil price changes variable is to show how much the variations in oil price contributes to inflation. Equally important, output gap variable is used to capture the effects of aggregate demand on inflation. On the other hand, the role of depreciation and its impacts on consumer price has given attention in literature. Scholars argue that short-run consumer price inflation unresponsive to exchange rate variations (Choudhri and Khan, 2002). The literature concerning exchange rate pass-through to inflation in Saudi Arabia is limited. However, a recent a study in this regard revealed a weak response of domestic prices to movements in exchange rate (Alkhareif et al., 2016). This paper could be criticized on the grounds that the mixture of independent variables hadan interaction with each other. By and large, VAR methodology is sensitive to the ordering of the variables.

It is imperative to test the exchange pass-through to consumer price inflation. Such testing will help in understanding the mechanism and process of prices determination in Saudi Arabia and redesigning properly the monetary policy in order to curb inflation. As it can be seen, Saudi economy is an external sector driven which will be influenced heavily with any external shocks, so keeping internal sector competitive requires an appropriate smooth exchange rate adjustments. Equally important, knowing the degree and timing of pass-through is extremely important for keeping monetary policy in a good shape. Targeting inflation however, compels complete knowledge of the speed of the pass-through. The significance of this study stems from the fact that the extent of pass-through of exchange rate into inflation is indeed influential on the monetary policy. Hence, the forecast of future prices helps adequately in determining the monetary policy. The aim of this paper is to investigate theoretically and empirically the exchange rate pass-through into inflation using ARDL co-integration approach. It's of interest to determine the short-run and long-run exchange rate passthrough into inflation and make sure that this model is stable and suitable for drawing policy suggestions. Furthermore, the exchange rate is considered among other variables, such as output gap and symmetric oil price movements. The rationale behind this is that, studies showed that these variables do play a major role in shaping and affecting inflation in economic literature (B Imimole, 2011). To sum up, this paper is an attempt to address the importance of exchange rate pass-through into inflation especially in an emerging oil-based economy and to demonstrate the role of oil price shocks in explaining the changes in inflation among other variables. It is clear that any oil price shocks (from the point of view of an oil-exporting country), affect inflation. Identically, exchange rate fluctuations and the aggregate demand (output gap) contribute to inflation. Similarly, adaptive expectations of inflation had a major role in determining inflation. The importance of this analysis is because it differs from other studies in the following. First, ARDL methodology is applied to test the short-run and long-run relationships between Consumer Price Inflation (CPI), as a dependent variable against symmetric oil price shocks OP ${ }^{\text {shocks }}$, log nominal bilateral (EX) and Output gap measured as GDP-GDP potential divided by GDP potential. Secondly, this analysis is directed towards the exchange rate passthrough and its contribution into inflation. Furthermore, the Saudi Riyal peg affects the Saudi import prices indirectly. Thirdly, Handful studies have dealt with inflation as a consequence of fiscal policy. However in this study, I used output gap as a measurement of aggregate demand instead of fiscal policy. The assumption of this paper is that the dynamics of inflation changes are affected and influenced by bilateral exchange rate, symmetric oil price variations and proxy for aggregate demand. To quantify and analyze this assumption empirically the auto regressive distributed lag, ARDL co-integration is applied. The fundamental empirical finding is that, bilateral exchange rate and symmetric oil price shocks are directly detrimental to consumer price inflation in the long-run while aggregate demand influence is almost negligible. On the other hand, Fig. 1 explains well the variations in the major variables under study over time. It is notable that oil prices play a major role in affecting the Saudi variables and the economy as a whole.

The structure of this paper as follows: Section 1 an introduction. Section 2 reviews and analyzes the theoretical and empirical related literature. Section 3 materials and methods that include development of theoretical model, estimation and discussions of the empirical results and their implications and section 4 presents a summary of the results and policy suggestions. 


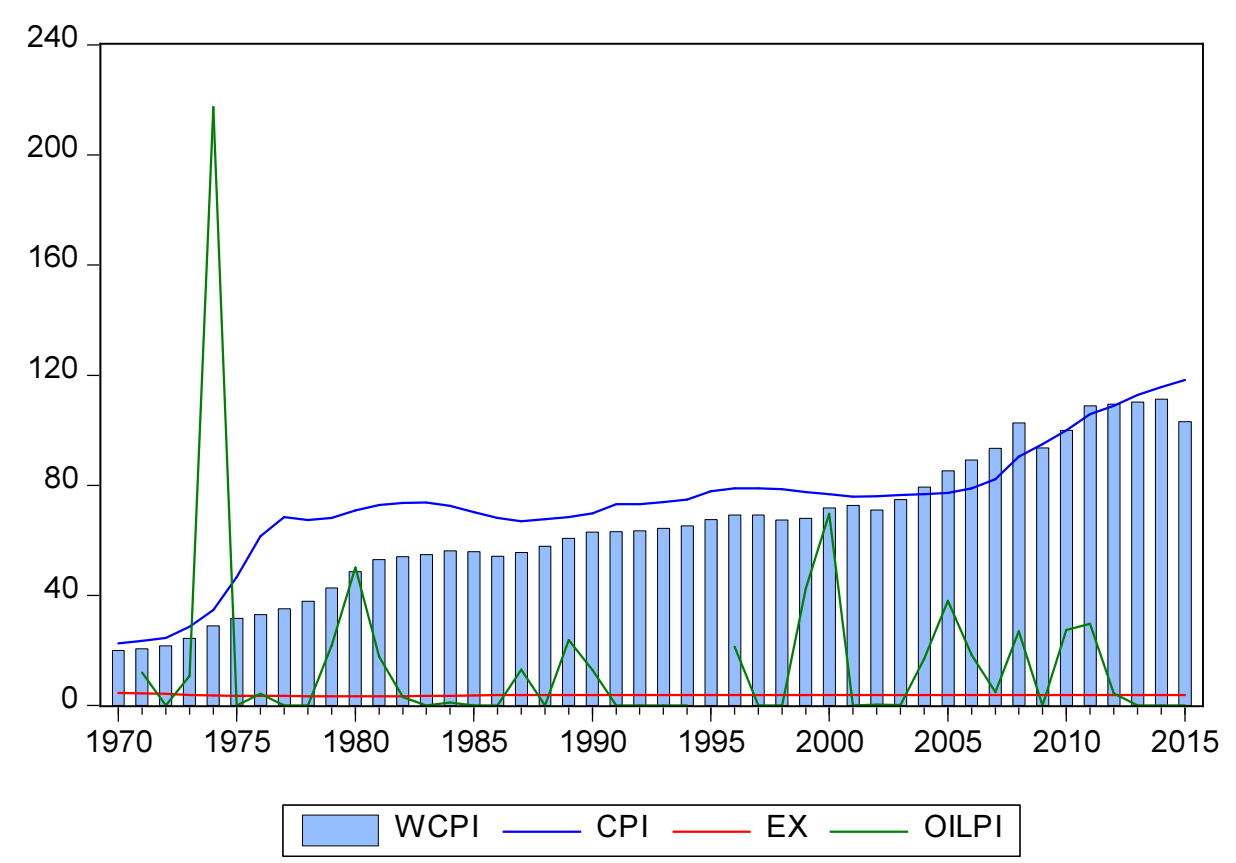

Fig. 1: Consumer and world price index, oil price increase and nominal exchange rate

\section{Review of Related and Empirical Literature}

Exchange rate and its relation with inflation constitute a cornerstone debated issue in macroeconomics. While causes of inflation are attributed to domestic and international factors, exchange rate is considered as a source disturbance and studied extensively in literature. It is clear that there are several factors determining the exchange rate. These factors include domestic and international prices, interest rate changes, political stability, balance of payments status, budget deficit and the percentage of public debt (Omoniyi and Olawale, 2015). McCarthy (2000) has examined the effects of exchange rate variations on domestic consumer price and producer price indices for some industrialized countries. VAR model is implemented using a distribution sequence of prices. The estimation is for the period after Bretton Woods's agreement, the IR is showed little effect on domestic inflation, whereas import prices are heavily affected. The pass-through effect is significant in economies with a significant share and more continual exchange rates and import prices. Between 1996 and 1998, the external factors alluded to had disinflation impacts in many countries under study except the US.

The relationship between exchange rate variations and the consequences on inflation are discussed extensively in literature. Choudhri and Khan (2002) questioned the validity of association between rupee devaluation in Pakistan and inflationary pressures. They proved in their paper that consumer prices unresponsive to exchange rate in the short-run. Their argument is built on reviewing recent literature as they pointed out. To carry on this conclusion, empirical tests are conducted for the period of 1982-2001 to see whether consumer price inflation is systematically related to exchange rate changes. They concluded that there is no association between rupee devaluation in Pakistan and consumer price inflation. The facts do not support that devaluation of rupee affects inflation.

Hüfner and Schröder (2002) examined exchange rate pass-through to consumer prices for five of the Euro area Germany, France, Italy, Netherlands and Spain. They used Vector Error Correction model (VEC) employing weights of the Harmonized Index of Consumer Prices (HICP). They found that a $10 \%$ depreciation of euro nominal effective exchange rate increases HICP by $0.4 \%$ after 12 months. Total effect is about $0.8 \%$. Hence, consumer prices adjustment takes 3 years.

Along the pricing chain, exchange rate pass through in different Euro area prices are examined, Faruqee (2004) utilized VAR approach and analyzed joint euro area exchange rates and a system of euro prices in response to exchange rate shocks. He used impulse response functions to determine a new open economy macroeconomic model. Prices found to give incomplete pass-through. It is comparable to those of industrial countries. He found that in all countries under study, exchange rate pass-through to the consumer price index is significant and lower than import prices.

Edwards (2006) discusses the relationship between inflation targeting and the exchange rates. He elaborated on the following issues: The analysis of effective 
nominal exchange rates as a shock absorber in economies with targeted inflation. He explained well that this issue is similar to pass-through in magnitude. Equally important, he analyzed the volatility of exchange rate in economies with inflation targeting than in countries with different monetary policy orders. Furthermore, he discussed whether exchange rate determines monetary policy stance or whether exchange rate had an independent position in an open economy or not.

Ca'Zorzi et al. (2007) tested empirically the extent of Exchange Rate Pass-Through (ERPT) to prices in 12 emerging economies in Asia, Latin America and Central and Eastern Europe. They employed three alternative vector autoregressive models. Their results contradicted the conventional wisdom that exchange rate passthrough to import prices and inflation are always higher in developing countries than in developed countries. In Asian economies, with a one digit inflation passthrough to import prices and inflation is low and comparable to developed countries. When Argentina and Turkey are excluded from analysis, there existed positive relationship between exchange rate passthrough and inflation. This is consistent with Taylor's hypothesis. They found also weak empirical support for the positive relationship between import openness and exchange rate pass-through.

Omotor (2008) tests for the effects of exchange rate variation on consumer price inflation in Nigeria for the period of 1970-2003. Vector error correction and slopedummy models are implemented. The purpose was to see the effects of government policy shifted exchange rate reform on consumer price inflation. The findings showed that exchange rate reform is powerful in shaping inflation. VEC decomposition shows that money supply and exchange rate positively influence inflation. On the other hand, slope-dummy indicates that flexible exchange rate does influence inflation. He suggests that a stable complementary policy on money supply and exchange rate of importance to stabilize inflation and output especially agricultural products to satisfy the increase in population needs.

Abimbola and Babatunde (2009) test empirically the impacts of exchange rate pass-through into import prices in Nigeria for the period 1980-2006. They used Unconditional Error Correction Model bounds test (UECM-Bounds) in order to tackle this issue. Empirical results reveal that world export prices play the major role in determining and explaining the movements in import prices in Nigeria for the same period relative to the exchange rate in the short-run and the long-run. They concluded that world export prices seem to be the key figure in determining domestic import prices than exchange rate policies.

Khan et al. (2009) argue that expansion economic policies in Pakistan, which were fruitful, have resulted in an increase in the consumer price index CPI. The stimulus policies resulted in an open discussion among economists. They adopted an econometric framework emphasizing the importance of identifying sources of inflation in Pakistan. They utilized data from 1972-73 till 2005-06, using OLS. They concluded that in the year 2005-06 adaptive expectations, credit to private sector and imported prices were responsible for the major determinants of inflation in Pakistan. Yet, fiscal policy had less contribution to inflation for the period under study.

B Imimole (2011) examines the effects of exchange rate depreciation on inflation for Nigerian economy for the period of 1986-2008. Autoregressive Distributed Lag (ARDL) co-integration is implemented. He found that exchange rate depreciation, money supply and gross domestic product were the main determinants affect inflation in Nigeria. He concluded that exchange rate depreciation and lag cumulative inflation affect consumer price inflation. Furthermore, despite the improvements in production due to naira depreciation, it is not considered a suitable measure to control inflation. Exchange rate depreciation should be coupled with other macroeconomic measures to stabilize the Nigerian economy.

Auda and Amaegberi (2013) consider the effects of exchange rate variations on inflation targeting in Nigeria covering the period of 1970-2012. Their findings suggest that the theoretical requirements for the variables implemented in this analysis are in line with statistical requirements which could be chosen as a satisfactory model. The long-run results show a significant relationship between interest rate and exchange rate. However, interest rate is positively affects the growth rate of inflation while affects exchange rate negatively. Stabilizing exchange rate will serve the economy in a positive manner. This will help boosting the economy exports and reduce dependence on imports.

Maka (2013) tested empirically asymmetric response of CPI inflation to changes in nominal exchange rate for Ghanaian economy for the period of 1990m1-2011m12. He employed Structural Vector Autoregressive (SVAR) model with more attention being paid to New Keynesian macroeconomic theory. He examined both symmetric and asymmetric exchange rate pass-through to CPI inflation. He found a strong evidence of repose of CPI inflation to exchange rate variations. The response featured three months in the future then disappears. Similarly, he found that the pass-through to non-food prices is complete, but incomplete for food prices. Exchange rate pass-through is asymmetric with depreciation and having the positive impact on inflation. However, appreciation had minor impact on CPI inflation and is statistically insignificant. He also found that the magnitude of changes in exchange rate do not affect the pass-through. On the other hand, he 
found that in periods of high inflation, inflation responds highly to output gap and exchange rate than in periods of declining inflation.

Mirdala (2014) explains that exchange rate variations determine the pass-through effects and absorption of exchange rate. Transmission of outside shocks to the economy is a nowadays discussion among experts. He examines the exchange rate pass-through to consumer prices in European transition economies. He employed VAR model to investigate the adverse effects of exchange rates due to outside price shocks. He concluded that there exist different patterns of the exchange rate pass-through to CPI, depending on the exchange rate regimes and the unexpected variations. Countries with nominal exchange rate (pegging) would be lower vulnerability to price changes. Countries with flexible exchange rate, responsiveness of exchange rate to oil price shock is durable.

Ebiringa and Anyaogu (2014) study the relationships between exchange rate, inflation and interest rates using ARDL co-integration in the Nigerian economy for the period 1971-2010. Their aim was to tackle stability in exchange rate through stable association of interest rate and inflationary movements and targeting. They found a stable and significant short-run and long-run positive relationship between inflation and exchange rate. On the other hand, interest rate showed negative relationship but insignificant. They concluded that government efforts are appreciated if kept inflation at the minimum to ensure stability of exchange rate.

Ude and Anochie (2014) focused on formulating multi linear regression models to examine empirically the effects of exchange rate pass-through on monetary policy and stability of domestic prices in Nigerian economy for the period of 1986:1-2014:4. Their findings reveal complete exchange rate pass-through to selected monetary policy variables with the exception of interest rate. On the other hand, they found incomplete passthrough to price stability. They recommended an election of an appropriate monetary policy instruments and exchange rate regime to stabilize the Nigerian economy.

Morosan and Zubas (2015) tackle the correlation between interest rate, exchange rate and inflation in Romanian economy for the period 2005-2014. They explained the importance of the effects of these three variables on the economical balance. They discussed the relationships between these variables theoretically and empirically. They applied regression analysis in order to establish interdependence between these variables. They tested several hypotheses for each variable of the set of three to determine which of these influence more. They concluded that the effects of exchange rate and inflation did have a delayed effect.

Cheikh and Rault (2015) presented an update estimates on the exchange rate pass-through on 12 euro countries. They started with quarterly data for the period 1990-2012. For this period of time they concluded that there is no significant heterogeneity in the degree of pass-through comparing to earlier studies. This heterogeneity is warranted, since the process of monetary union made it possible for stable macroeconomic policies among the 12 countries. They found a decline in exchange rate pass-through estimates beginning of the year 1990. This happened because of the shift to reduction of inflation regimes. Also, passthrough has significantly declined in the last two decades regardless of the state of the country whether it core economy of the 12 countries or not.

Omoniyi and Olawale (2015) estimated the relationship between exchange rate, crude oil prices and inflation using ARDL approach. They covered the Nigerian data for the monthly period ranging from 2004 up to 2014. Their findings reveal that macroeconomic variables have strong and significant relationship with the exchange rate. However, conditional level relationship model and Error Correcting Model (ECM) in the short and long-run exhibited negative relationship between crude oil prices with the exchange rate and positively related to exchange rate. The speed of adjustment to the long-run showed a slow speed in reaction to crude oil prices shocks and inflation rates.

Alkhareif et al. (2016) examined responses of domestic prices to exchange rate pass-through in Saudi Arabia for the period 1985-2015. The aim is to test the relationship between changes in domestic prices due to changes in exchange rate using Vector Autoregressive (VAR) approach. The employed several variables among them output gap, the ratio of imports to non-oil GDP and opened letters of credit to finance imports. They found weak response of domestic prices to exchange rate variations. They attributed this weakness to incomplete competition in domestic market.

Lariau et al. (2016) tested and estimated the exchange rate pass-through to consumer price inflation in two African countries, Angola and Nigeria with more attention is being paid to variations of the pass-through over time. Although, Angola and Nigeria are characterized with dependence on oil exports, the test findings revealed that pass-through are different. Their results showed that exchange rate pass-through to inflation is high in Angola, but diminishes over time reflecting the so called dedollarization of Angolan economy. By the same token, long-run relationship between exchange rate and inflation is not stable and showed no significant pass-through effect to inflation. However, pass-through impact on main inflation is significant.

Abdurehman and Hacilar (2016) tackled the issue of exchange rate and its relation with inflation in Turkey. Their work concentrated on inflation data of Turkey and the United Kingdom. This work is different from earlier 
empirical studies which used inflation data of Turkey and the United States, to examine the relationship between inflation in Turkey and the exchange rate. They employed Ordinary Least Squares (OLS) and GARCH to test this relationship. Their findings from OLS confirm that there is no existence of Purchasing Power Parity (PPP). Furthermore, the presence of ARCH and GARCH indicate that the deviation from PPP are not random but follow a particular pattern. They concluded that the deviation of PPP might be due to transaction cost, government regulations and specialization in production.

The magnitude and length of exchange rate passthrough have been discussed in the literature. The importance of this lies in its economic consequences on price and exchange rate stability. Bada et al. (2016) examined the exchange rate pass-through effect into import and consumer prices in the Nigerian economy covering the period of 1995Q1-2015Q1. To carry this task, they employed Johansen approach to co-integration and vector error correction model. They found that exchange rate pass-through into Nigeria's consumer price inflation is incomplete. The long-run pass-through elasticities were 0.24 and 0.30 for alternative models. Their results were higher for import price than consumer prices which means that the pass-through effect declines along the pricing chain. These results offer a good guide for monetary and exchange rate policies of Nigeria central bank. Likewise, Jobarteha and Yeboua (2016) studied the exchange rate pass-through to consumer prices for Gambia covering the monthly period of $2001 \mathrm{~m} 12-2012 \mathrm{~m} 12$. They applied Johansen cointegration and Vector Error Correction Model (VECM) approaches. Their finding is that, adjustment process to equilibrium is slow and that exchange rate pass-through into inflation is incomplete. From impulse response function, a $1 \%$ depreciation in the exchange rate increases inflation by $0.12 \%$ in two years. However, variance decomposition reveals that exchange rate is contributing up to $35 \%$ of changes in inflation.

Forero and Vega (2016) examined the extent of exchange rate innovations pass-through to core inflation in a nonlinear content with attention being paid to positive (depreciation) and negative (appreciation) exchange rate shocks in Peruvian economy. In accordance they constructed a nonlinear Structural Vector Autoregressive (SVAR) model. They computed impulse response functions for core inflation after exchange rate variations. With the use of bootstraps Monte Carlo routine, results for Peruvian economy revealed statistically significant asymmetry in response of core inflation. Furthermore, a depreciation shock is about twice as the size of appreciation after one year. Hence, exchange rate pass-through to price is about $20 \%$ under depreciation while $10 \%$ under an appreciation.

Comunale and Kunovac (2017) investigated the exchange rate pass-through in the euro area as a whole and in specific four European countries Germany, France, Italy and Spain. They used Bayesian VAR. Furthermore, they implemented identification restrictions on zero and sign. They concluded after a rigorous and extended work that exchange rate passthrough is not constant over time. It depends on a combination of shocks that govern exchange rate. Finally, it is clear that the effect of exchange rate passthrough is relatively stronger if stimulated by monetary policy shocks and exchange rate shocks. The exchange rate pass-through is small in the euro area, but the passthrough to import price large and volatile.

Fareed et al. (2017) examined the exchange rate overshooting and its effect on balance of trade in Pakistan for the period of 1971-2015. Their goal is to check the short-run and long-run relationship between exchange rate overshooting and the balance of payments. They utilized auto regressive distributed lags approach in order to achieve this task. They found that exchange rate has a positive and significant relationship with balance of trade in the short-run and the long-run. On the other hand, devaluation of rupees against the US dollar would result in an increase in Pakistan's exports and trade balance will be improved. Consumer price inflation and the money supply have negative and significant relationship with trade balance in the long-run. Excess money supply causes inflation which affects exports negatively. Government should encourage policies that lead to more exports and hence, economic growth.

\section{Materials and Methods}

\section{The Model}

Following McCarthy (2000), the model will be adopted into an eclectic model to allow some features of Saudi economy to be present. In order to test passthrough changes of exchange rates and import price to producer and consumer indices, he used a model with pricing with a distribution chain. Import, producer and consumer prices in period $t$ are assumed to include several factors. Expected inflation depends on the available information in period $t-1$. Supply and demand shocks on inflation are at time $t$. In addition, the exchange rate shocks on inflation are at a specific point in time. Moreover, the impacts of shocks are at the former stages of the chain. Finally, shocks at each stage come from stages inflation of unexpected information at time $t-1$. By the same token, unexplained inflation at time $t-1$ contains contemporaneous inflation about supply and demand and inflation at time $t-1$ exchange rates. The shocks could be considered as variations in the pricing power and markups of firms. The main feature of the model is that, it permits import price shocks to influence consumer price index, CPI directly and indirectly through 
the impacts on producer price index, PPI. Not to mention that the model does not include contemporaneous feedback. Taking into consideration, former assumptions on inflation rates are of country I in time $t$, given the three stages import price, PPI and CPI such that:

$$
\begin{aligned}
& \pi_{i t}{ }^{m}=E_{t-1}\left(\pi_{i t}{ }^{m}\right)+\delta_{1 i} \varepsilon_{i t}{ }^{s}+\delta_{2 i} \varepsilon_{i t}{ }^{d}+\delta_{3 i} \varepsilon_{i t}{ }^{e}+\varepsilon_{i t}{ }^{m} \\
& \pi_{i t}{ }^{w}=E_{t-1}\left(\pi_{i t}{ }^{w}\right)+\theta_{1 i} \varepsilon_{i t}{ }^{s}+\theta_{2 i} \varepsilon_{i t}{ }^{d}+\theta_{3 i} \varepsilon_{i t}{ }^{e}+\theta_{4 i} \varepsilon_{i t}{ }^{m}+\varepsilon_{i t}{ }^{w} \\
& \pi_{i t}{ }^{c}=E_{t-1}\left(\pi_{i t}{ }^{c}\right)+\psi_{1 i} \varepsilon_{i t}{ }^{s}+\psi_{2 i} \varepsilon_{i t}{ }^{d} \\
& +\psi_{3 i} \varepsilon_{i t}{ }^{e}+\psi_{4 i} \varepsilon_{i t}{ }^{m}+\psi_{5 i} \varepsilon_{i t}{ }^{w}+\varepsilon_{i t}{ }^{c}
\end{aligned}
$$

where, $\pi_{i t}{ }^{m} \pi_{i t}{ }^{w}$ and $\pi_{i t}{ }^{c}$ are import price, CPI and PPI. $\varepsilon_{i t}^{s}, \varepsilon_{i t}{ }^{d}$ and $\varepsilon_{i t}{ }^{e}$ are supply, demand and exchange rate shocks. $\varepsilon_{i t}{ }^{m}, \varepsilon_{i t}{ }^{w}$ and $\varepsilon_{i t}{ }^{c}$ are import price, CPI and PPI. The $E_{t-1}(\cdot)$ is expectations of each variable set at time $t$ 1. Furthermore, shocks are not serially correlated with each other at any point in time. According to him, the structure Equations 1 to 3 indicate as if they are part of recursive VAR. He suggested three more restriction on the model. Supply shocks are specified from oil price which is denominated in home currency. Equally important, demand shocks are specified by output gap. Finally, exchange rate shocks are specified through exchange rate appreciation. The equations can be written as:

$$
\begin{aligned}
& \pi_{i t}^{o i l}=E_{t-1}\left(\pi_{i t}{ }^{o i l}\right)+\varepsilon_{i t}{ }^{s} \\
& \tilde{y}_{i t}=E_{t-1}\left(\tilde{y}_{i t}\right)+\lambda_{1 i} \varepsilon_{i t}{ }^{s}+\varepsilon_{i t}{ }^{d} \\
& \Delta e_{i t}=E_{t-1}\left(\Delta e_{i t}\right)+\zeta_{1 i} \varepsilon_{i t}{ }^{s}+\zeta_{2 i} \varepsilon_{i t}{ }^{d}+\varepsilon_{i t}{ }^{e}
\end{aligned}
$$

\section{Empirical Methodology}

This paper links factors affecting inflation based on the forgone analysis. In the normal case there will be a monetary policy reaction to the variations of the exchange rates thereby policy influencing exchange rates and domestic prices. Since, I'm not intended to examine the consequences of a monetary policy reaction to exchange rate volatility, nor policy effects on consumer price index, this work will be constructed as a log-linear eclectic model specified to include the following suitable variables:

$$
I N F_{t}=\eta_{0}+\eta_{1 t} \text { OP } P^{\text {shock }}+\eta_{2 t} \text { Output } \text { tap }^{\text {ga }}+\eta_{3 t} E X+V_{t}
$$

where, $I N F_{t}$ is the Consumer Price Inflation (CPI). $O P_{t}^{\text {shock }}$, Output ${ }_{t}^{\text {gap }}$ and $E X_{t}$ are the symmetric oil price shock, Output gap represents aggregate demand and bilateral nominal exchange rate changes respectively.
In economic literature, Auto Regressive Distributed Lags (ARDL) has been presented and applied first by Pesaran et al. (2001) with the characteristics of not requiring all variables to be stationary at $I(1)$ or $I(0)$. As has been noted, in bounds testing co-integration all variables included in the analysis is to be endogenous. However, the first order of variables either $I(1)$ or $I(0)$ but not $I(2)$ and short-run and long-run coefficients of the models are tested and estimated simultaneously. The $\operatorname{ARDL}(p, q)$ model can be specified as unrestricted error correction version as:

$$
\begin{aligned}
& \Delta \text { Inf }=\beta_{0}+\sum_{i=1}^{n} \beta_{1 i} \Delta \operatorname{Inf}_{t-i}+\sum_{i=0}^{n} \beta_{2 i} \Delta E x_{t-i} \\
& +\sum_{i=0}^{n} \beta_{3 i} \Delta O P_{t-i}+\sum_{i=0}^{n} \beta_{4 i} \Delta \text { Output }^{\text {gap }}{ }_{t-i}+\lambda_{1} \\
& \operatorname{Inf}_{t-1}+\lambda_{2} \text { Ex }_{t-1}+\lambda_{3} O P_{t-1}+\lambda_{4} \text { Output }^{\text {gap }}{ }_{t-1}+e_{1 t}
\end{aligned}
$$

where, $\beta_{t i}$ with $t=1,2,3$ and 4 represents short-run dynamic coefficients. The model includes log inflation and real $\log$ output gap which is calculated as: Real GDP-potential GDP/potential GDP, besides log nominal bilateral exchange rate. Exchange rate is defined as the number of units of domestic currency (Riyal) per US dollar. The depreciation of the domestic currency leads to a rise in import values which will be added to domestic origin of inflation. Moreover, further depreciation may cause fear to people inducing them to buy more goods which may worsen the situation. In this study $\Delta$ denotes first difference operator and $e_{t}$ is the white noise residuals. The left hand side represents the change in consumer price inflation. $\lambda_{1}-\lambda_{4}$ represents the long-run relationships while $\beta_{1}-\beta_{4}$ represents the shortrun dynamics of the model under consideration. Given these points, the existence of long-run relationships among the variables $I N F, E x$, Output ${ }^{\text {gap }}$ and OP, bound testing is performed and depends on $F$-test which examines the existence of co-integration (long-run relationships) among the variables under study. If $F$ value is greater than upper bound, then rejects $H_{0}$ and there exists co-integrated variables, such that:

$$
H_{0}: \lambda_{1}=\lambda_{2}=\lambda_{3}=\lambda_{4}=0
$$

Similarly, if F-value is less than lower bound, $H_{0}$ is accepted and variables are not co-integrated. Hence, in case of no long-run relationships among the variables, then:

$$
H_{1}: \lambda_{1} \neq \lambda_{2} \neq \lambda_{3} \neq \lambda_{4} \neq 0
$$

The correction model of the short-run relationships used in this analysis is specified as follows:

$$
\begin{aligned}
& \Delta \text { Inf }=\beta_{0}+\sum_{i=1}^{n} \beta_{1 i} \Delta \operatorname{Inf}_{t-i}+\sum_{i=0}^{n} \beta_{2 i} \Delta E x_{t-i} \\
& +\sum_{i=0}^{n} \beta_{3 i} \Delta O P_{t-i}+\sum_{i=0}^{n} \beta_{4 i} \Delta \text { Output }^{\text {gap }}{ }_{t-i}+\theta_{1} E C M_{t-1}+u_{1 t}
\end{aligned}
$$


It is expected that $\mathrm{ECM}_{\mathrm{t}-1}$ with $\theta_{1}$ is negative and significant indicating that any disequilibrium between the dependent variable and the explanatory variables will converge to the long-run equilibrium at a certain speed given by the magnitude of $\theta_{1}$.

\section{Estimation and Discussions}

\section{The ARDL Unit Root Testing}

The ARDL lag length is one of the features that characterize the use of this approach where it assigns different lags to different variables involved in the study. The order selection criterion can be easily achieved through unrestricted VAR such as SIC, AIC and so on. The strength of Akaike information criteria over other criterion is based on the following fact, 20 different ARDL models are performed. The lower value of AIC will be selected, that is $(2,4,0,4)$ gives the lowest values of AIC. Figure 2, exhibits the strength of the model selection criteria.

According to Nkro and Uko (2016), the general Augmented Dickey-Fuller (ADF) test is set as:

$$
\Delta Y_{t-1}=\delta_{0}+\rho_{1} Y_{t-1}+\delta_{2} T+\sum_{i=1}^{k} \delta i \Delta Y_{t-i}+u_{t}
$$

where, $u_{t}$ is a white noise error term. $\Delta Y_{t-1}=\left(Y_{t-1}-Y_{t-2}\right)$, $\Delta Y_{t-1}=\left(Y_{t-1}-Y_{t-2}\right)$, is the number of lagged difference terms which included so that error terms are serially uncorrelated and $k$ is lagged value $\Delta Y$ with the assumption that series follow an $A P(\rho)$. However, $\rho=$ 0 can be tested following the same asymptotic distribution as in Dickey-Fuller test. In accordance, an ADF value with less than its critical value, series are non-stationary. The results of unit root tests for the series of inflation, output ${ }^{\text {gap }}$, exchange rate and symmetric oil price shocks are reported in Table 1. ADF and PP taken on level and first difference with pvalues for the series are somewhat mixed. Inflation is significant at the 1 and $5 \%$ level $I(0)$ but unfortunately is not significant at $I(1)$ in both ADF and PP tests. The rest of the series are significant at 1,5 and $10 \%$ level in both test with the exception of symmetric oil price shocks where it is not significant at level in both tests.

Having set the order of integration of series, the task is to determine the number of long-run relationships (cointegrating vectors) among the variables. The results for Johansen co-integration tests show that the series inflation, output ${ }^{\text {gap }}$, exchange rate and symmetric oil price variations are co-integrated. Table 2 reveals that null hypotheses of no co-integration among the variables $(\mathrm{r}=0)$ is rejected at $5 \%$ level of confidence. Trace and Max tests show the existence of long-run relationship between the series alluded to.

Akaike Information Criteria (top 20 models)

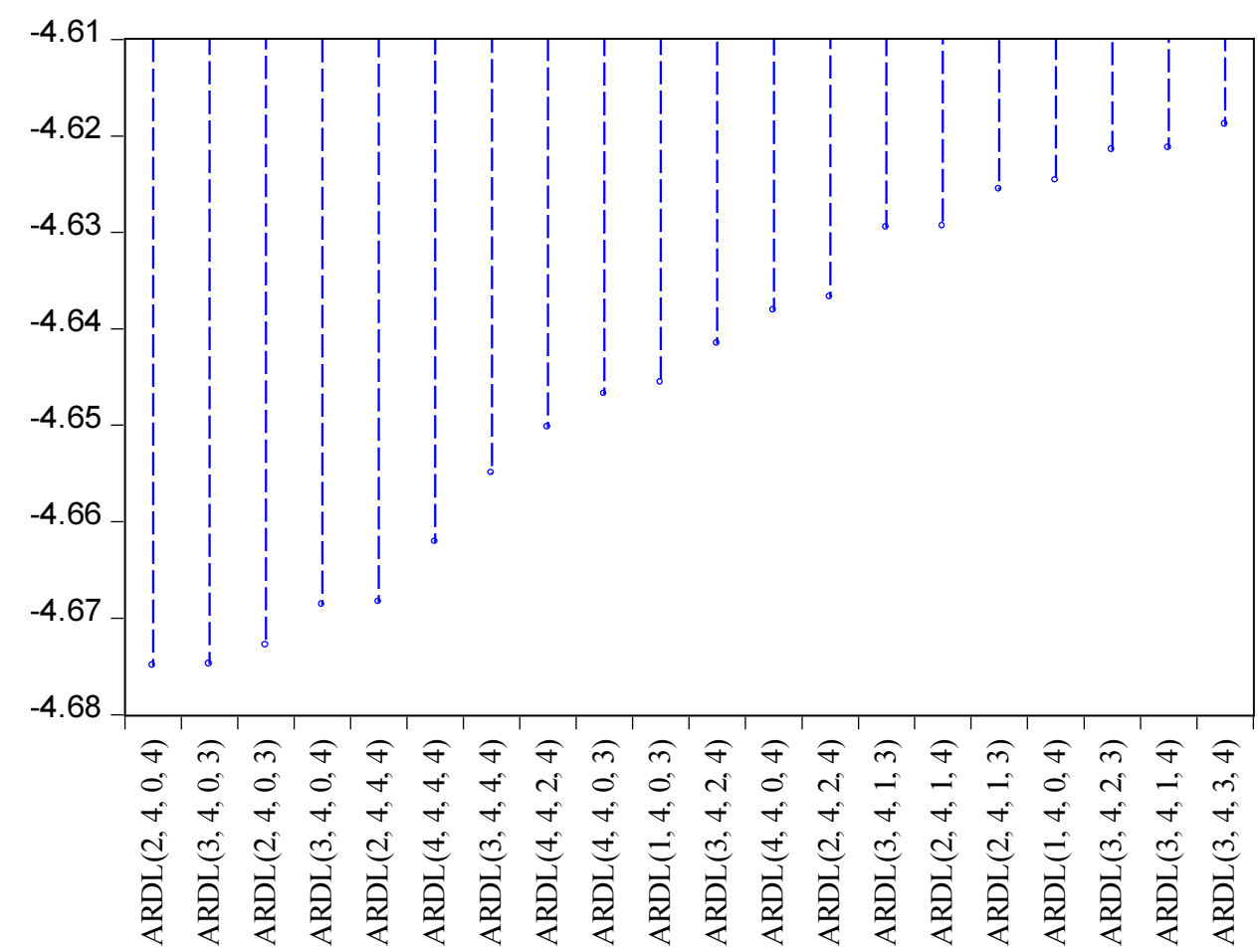

Fig. 2: The strength of model selection criteria 
Table 1: Augmented-dickey fuller and Phillips-Perron tests

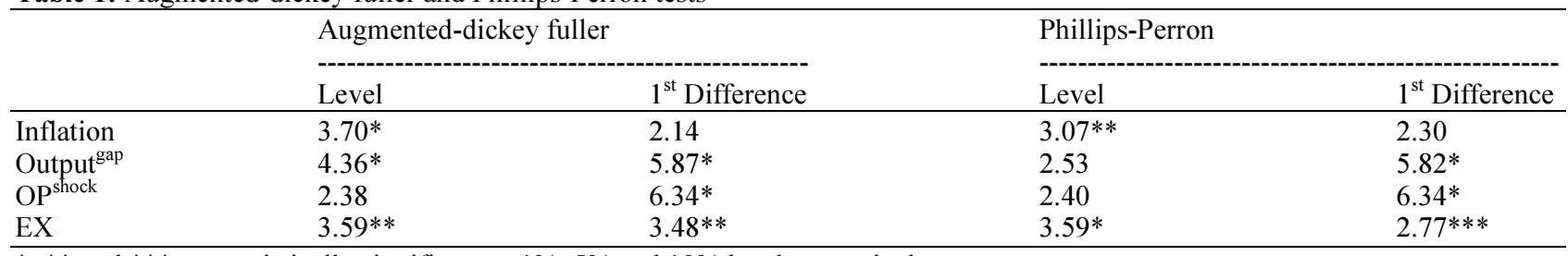

${ }^{*}, * *$ and $* * *$ are statistically significant at $1 \%, 5 \%$ and $10 \%$ level respectively.

Table 2: Johansen co-integration test

With OP ${ }^{\text {shock }}($ lags $=3$ )

\begin{tabular}{|c|c|c|c|c|c|c|c|c|}
\hline $\mathrm{H}_{0}$ & $\mathrm{H}_{\mathrm{A}}$ & Eigenvalues & $\lambda_{\text {Trace }}$ & $95 \%$ & $\mathrm{H}_{0}$ & $\mathrm{H}_{\mathrm{A}}$ & $\lambda_{\operatorname{Max}}$ & $95 \%$ \\
\hline$r=0$ & $r=1$ & 0.479360 & 46.98219 & 29.79707 & $r=0$ & $r=1$ & 27.41327 & 21.13162 \\
\hline$r=1$ & $r=2$ & 0.366068 & 19.56891 & 15.49471 & $\mathrm{r}=1$ & $r=2$ & 19.14416 & 14.26460 \\
\hline$r \leq 3$ & $r=4$ & 0.010062 & 0.424756 & 3.841466 & $\mathrm{r} \leq 3$ & $r=4$ & 0.010062 & 3.841466 \\
\hline
\end{tabular}

Table 3: The ARDL regression

\begin{tabular}{|c|c|c|c|c|}
\hline Variable & Coefficient & Std. Error & t-Statistic & Prob.* \\
\hline LINF(-1) & 1.104958 & 0.124605 & 8.867676 & 0.0000 \\
\hline LINF(-2) & -0.188455 & 0.111045 & -1.697110 & 0.1008 \\
\hline OUTPUT $^{\text {GAP }}$ & $4.10 \mathrm{E}-06$ & $2.97 \mathrm{E}-06$ & 1.381278 & 0.1781 \\
\hline LEX & 0.397889 & 0.477606 & 0.833091 & 0.4118 \\
\hline LEX(-1) & -0.156030 & 0.779053 & -0.200281 & 0.8427 \\
\hline $\operatorname{LEX}(-2)$ & -0.704860 & 0.679344 & -1.037560 & 0.3084 \\
\hline $\operatorname{LEX}(-3)$ & -0.290498 & 0.678043 & -0.428436 & 0.6716 \\
\hline $\operatorname{LEX}(-4)$ & 1.387893 & 0.409799 & 3.386766 & 0.0021 \\
\hline LOP & 0.003887 & 0.016845 & 0.230761 & 0.8192 \\
\hline $\mathrm{LOP}(-1)$ & -0.006676 & 0.018091 & -0.369001 & 0.7149 \\
\hline LOP(-2) & 0.013255 & 0.017399 & 0.761827 & 0.4525 \\
\hline LOP(-3) & 0.018970 & 0.017062 & 1.111822 & 0.2757 \\
\hline $\mathrm{LOP}(-4)$ & 0.015093 & 0.012630 & 1.195007 & 0.2421 \\
\hline $\mathrm{C}$ & -0.609263 & 0.149271 & -4.081582 & 0.0003 \\
\hline R-squared & 0.993972 & Mean dependent var & & 4.333894 \\
\hline Adjusted R-squared & 0.991173 & S.D. dependent var & & 0.218262 \\
\hline S.E. of regression & 0.020507 & Akaike info criterion & & -4.674930 \\
\hline Sum squared resid & 0.011775 & Schwarz criterion & & -4.095706 \\
\hline Log likelihood & 112.1735 & Hannan-Quinn criter. & & -4.462621 \\
\hline F-statistic & 355.1242 & Durbin-Watson stat & & 1.689571 \\
\hline Prob(F-statistic) & 0.000000 & & & \\
\hline
\end{tabular}

Dependent Variable: INFLATION

Method: ARDL

Maximum dependent lags: 4 (Automatic selection)

Model selection method: Akaike Info Criterion (AIC)

Dynamic regressors (4 lags, automatic): OUTPUT ${ }^{\text {GAP }}$ LEX LOP $^{\text {shock }}$

Selected Model: ARDL $(2,0,4,4)$

\section{The ARDL Regression Model}

The estimation results are presented in Table 3. Consumer price inflation lagged one year is statistically significant at $1 \%$ level. A $10 \%$ increase in last year inflation leads to an $11 \%$ in consumer price inflation. This indicates that Saudis depend heavily of their price expectations on the last period prices. The depreciation of Saudi currency contributes about $40 \%$ to changes in inflation. Moreover, exchange rate lagged 4 years is statistically significant at $1 \%$. A $10 \%$ change in exchange rate (depreciation) contributes $13 \%$ to inflation. This indicates that the effects of exchange rate on inflation take time to be materialized. One reason could be the indirect effect of exchange rate on inflation. Saudi Arabian riyal is pegged to the US dollar since the 70s. By the same token, output ${ }^{\text {ap }}$ which represents the aggregate demand contributes almost nothing to inflation. This finding is consistent with the fact that Saudi Arabia is an open economy and no limits to absorptive capacity. The symmetric oil price shocks have the expected signs but unfortunately are not statistically significant. A $10 \%$ change in oil price contributes about $0.04 \%$ to inflation. When we compare the results 
obtained from the robust least square test, Table 4 , one note the consistency of results in comparison with ARDL test results, of course with the exception of output $^{\text {gap }}$ results. The $\mathrm{R}^{2}$ and DW test gave a good fit and no presence for serial correlation problem.

\section{The ARDL Short-Run, Long-Run and Bounds Testing}

Table 5, reveals the short-run coefficients and the error correction model estimates $\mathrm{ECM}_{\mathrm{t}-1}$ of the ARDL model. The error correction model has negative sign and significant at $1 \%$ level. Speed of adjustment of the short-run variables to the long-run equilibrium for the error correction model is somewhat low and is $8 \%$. The finding reflects that the last period's disequilibrium is corrected at the speed of $8 \%$ annually. One possible reason for the slow adjustment process is the indirect effect of exchange rate on inflation. According to results, effect of exchange rate will take place within four years. Last year inflation came with the exact sign and is statistically significant at $10 \%$ level. Moreover, exchange rate lagged two and three years are statistically significant with the negative sign. The findings indicate that in the shortrun depreciation has no impact on inflation. However, in the long run the signs of the variables are as expected earlier Table 6 . The exchange rate and the symmetric oil price shocks have the right signs and are statistically significant at $1 \%$ level. For the bounds testing, Table 7, F-statistics value is about $6.8 \%$ which is greater than the upper bound at all levels. This indicates the rejection of null hypothesis that there exists no co-integration among all variables.

Table 4: Robust least squares estimates of Inflation as a dependent variable

Dependent variable: Inflation

\begin{tabular}{|c|c|c|c|}
\hline Variables & Coefficient & z-statistic & Probability \\
\hline $\mathrm{C}$ & -0.104290 & -0.173711 & 0.8621 \\
\hline OP $\mathrm{P}^{\text {shock }}$ & 2.232053 & 5.631752 & 0.0000 \\
\hline Output ${ }^{\text {gap }}$ & $-9.86 \mathrm{E}-05$ & -0.674007 & 0.5003 \\
\hline EX & 2.771520 & 7.167590 & 0.0000 \\
\hline \multicolumn{4}{|l|}{$\mathrm{R}^{2}=0.27 \mathrm{R}^{2} \mathrm{~W}=0.59$} \\
\hline $\mathrm{R}^{2} \mathrm{n}=56.40$ & & & \\
\hline
\end{tabular}

Table 5: Error correction of ARDL model

\section{ECM Regression}

\begin{tabular}{|c|c|c|c|c|}
\hline Variable & Coefficient & Std. Error & t-Statistic & Prob. \\
\hline$\overline{\mathrm{D}(\mathrm{LINF}(-1))}$ & 0.188455 & 0.094875 & 1.986350 & 0.0569 \\
\hline $\mathrm{D}(\mathrm{LEX})$ & 0.397889 & 0.406906 & 0.977841 & 0.3365 \\
\hline $\mathrm{D}(\operatorname{LEX}(-1))$ & -0.392535 & 0.355284 & -1.104848 & 0.2786 \\
\hline $\mathrm{D}(\operatorname{LEX}(-2))$ & -1.097395 & 0.340145 & -3.226253 & 0.0032 \\
\hline $\mathrm{D}(\operatorname{LEX}(-3))$ & -1.387893 & 0.370997 & -3.740977 & 0.0008 \\
\hline D(LOP) & 0.003887 & 0.012253 & 0.317235 & 0.7534 \\
\hline $\mathrm{D}(\mathrm{LOP}(-1))$ & -0.047319 & 0.014452 & -3.274232 & 0.0028 \\
\hline $\mathrm{D}(\mathrm{LOP}(-2))$ & -0.034064 & 0.014174 & -2.403280 & 0.0231 \\
\hline $\mathrm{D}(\mathrm{LOP}(-3))$ & -0.015093 & 0.011254 & -1.341180 & 0.1906 \\
\hline $\operatorname{ECM}(-1)^{*}$ & -0.083496 & 0.013402 & -6.230005 & 0.0000 \\
\hline R-squared & 0.940571 & Mean dependent var. & & 0.033840 \\
\hline Adjusted R-squared & 0.923857 & S.D. dependent var. & & 0.069516 \\
\hline S.E. of regression & 0.019182 & Akaike info criterion & & -4.865406 \\
\hline Sum squared resid & 0.011775 & Schwarz criterion & & -4.451675 \\
\hline Log likelihood & 112.1735 & Hannan-Quinn criter. & & -4.713757 \\
\hline Durbin-Watson stat & 1.689571 & & & \\
\hline
\end{tabular}

ARDL Error Correction Regression

Dependent Variable: D(LCPI)

Selected Model: ARDL $(2,4,0,4)$

Included observations: 42

Table 6: Long run coefficients

\begin{tabular}{lllll}
\hline Variable & Coefficient & Std. Error & t-Statistic & Prob. \\
\hline LEX & 7.597860 & 2.063201 & 3.682559 & 0.0010 \\
OUTPUT $^{\text {GAP }}$ & $4.91 \mathrm{E}-05$ & $3.92 \mathrm{E}-05$ & 1.251723 & 0.2210 \\
LOP & 0.533318 & 0.134154 & 3.975412 & 0.0004 \\
C & -7.296874 & 2.978432 & -2.449904 & 0.0208 \\
\hline
\end{tabular}


The long-run coefficients and the short-run dynamics of the ARDL estimates are stable. Test of CUSUM and CUSUMQ are implemented. Figure 3 shows stability of the model. Table 8 and 9 revealed that there is not serial correlation, nor heteroskedasticity.
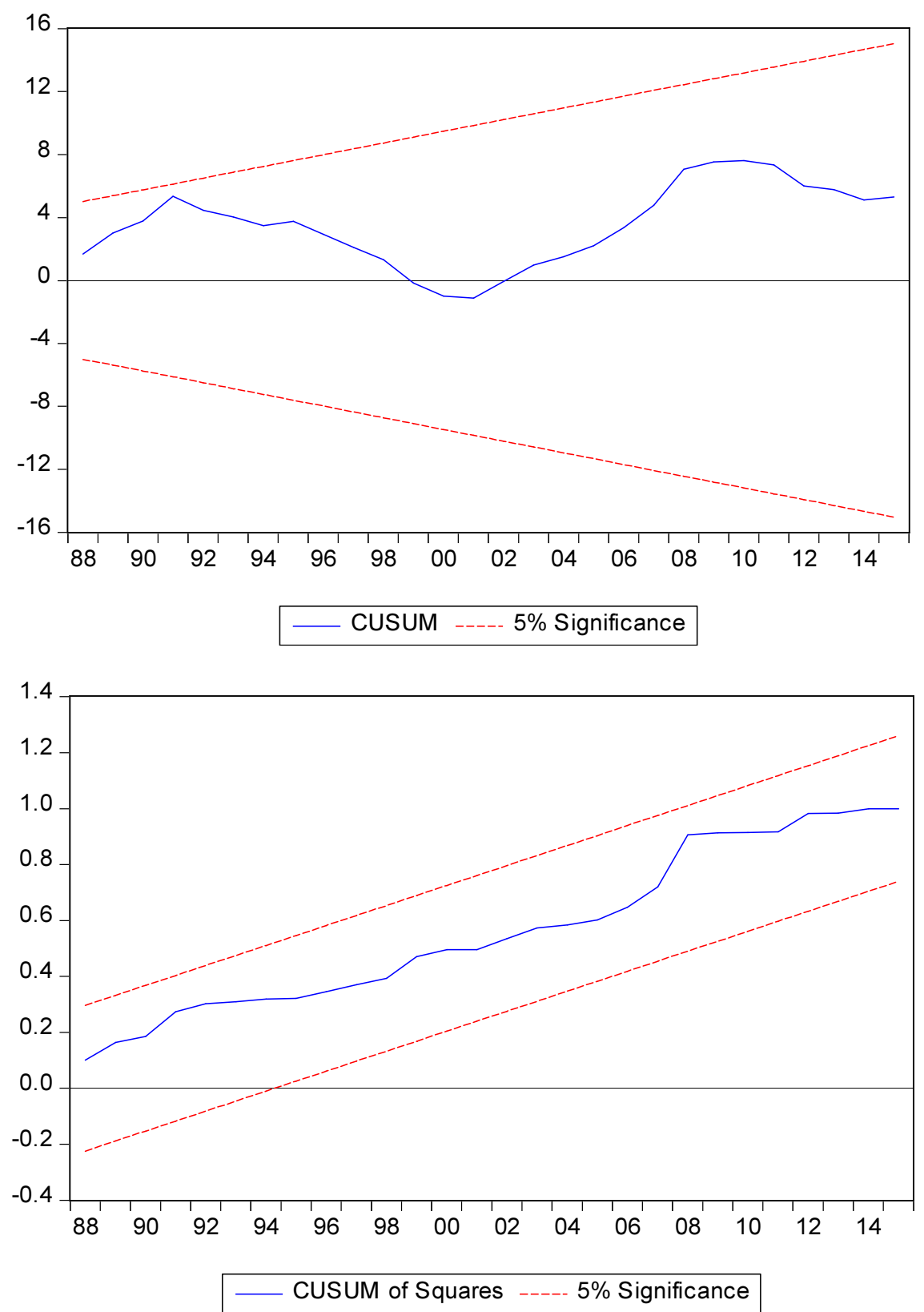

Fig. 3: CUSUM and CUSUMQ

Table 7: The ARDL Bounds testing

\begin{tabular}{|c|c|c|c|c|}
\hline \multicolumn{2}{|c|}{ F-Bounds Test } & \multicolumn{3}{|c|}{ Null Hypothesis: No levels relationship } \\
\hline Test Statistic & Value & Significant (\%) & $\mathrm{I}(0)$ & $\mathrm{I}(1)$ \\
\hline F-statistic & 6.792268 & 10.0 & 2.37 & 3.20 \\
\hline \multirow[t]{3}{*}{$\mathrm{k}$} & 3.000000 & 5.0 & 2.79 & 3.67 \\
\hline & & 2.5 & 3.15 & 4.08 \\
\hline & & 1.0 & 3.65 & 4.66 \\
\hline
\end{tabular}


Table 8: Serial correlation LM test

Breusch-godfrey serial correlation LM test

\begin{tabular}{llll}
\hline Breusch-godfrey serial correlation LM test & & \\
\hline F-statistic & 1.857841 & Prob. F(2,26) & 0.1761 \\
Obs*R-squared & 5.251727 & Prob. Chi-Square(2) & 0.0724 \\
\hline
\end{tabular}

Table 9: Heteroskedasticity Test

Heteroskedasticity Test: Breusch-Pagan-Godfrey

\begin{tabular}{lclr}
\hline F-statistic & 1.013331 & Prob. F(13,28) & 0.4658 \\
Obs*R-squared & 13.43780 & Prob. Chi-Square(13) & 0.4146 \\
\hline
\end{tabular}

\section{Conclusion and Policy Recommendations}

The purpose of this paper has been to analyze and estimate the exchange rate pass-through to consumer price inflation in Saudi Arabia for the period of 1970-2015. An eclectic ARDL model has been developed and tested based on the model developed by McCarthy (2000). Oil price and exchange rate are the main factors contributing to inflation in Saudi Arabia in the long-run. This paper implemented some of the factors that affect consumer price inflation and became the first effort to test exchange rate pass-through effects to consumer price inflation using the ARDL approach. In the short-run, the depreciation of lagged nominal bilateral exchange rate and lagged inflation explained well the major part of variations in domestic prices. Similarly, aggregate demand variable and the symmetric oil price changes had the expected signs but their impacts on domestic prices are minimal. It is interesting to note, that lagged exchange rate explains well the indirect impact of pegging Saudi riyal to the US dollar on the domestic prices. The depreciation of riyal causes imports to be expensive in the sense that costly imports will contribute to domestic inflation. In addition, this paper has examined exchange rate pass-through using Robust OLS and revealed consistency with ARDL results. The $\mathrm{ECM}_{\mathrm{t}-1}$ and the Johansen co-integration tests showed an existence of long-run relationships among the variables INF, EX, Output ${ }^{\text {gap }}$ and OP ${ }^{\text {shocks }}$. Equally important, shortrun dynamic adjustment to long-run equilibrium is low and $8 \%$. Correspondingly, the reduction of existing disequilibrium over time is of interest in order to maintain long-run equilibrium. Domestic inflation this year will continue suppressing and controlling factors cause domestic inflation next year. A possible explanation is that, lagged variable impacts take time (4 years) to passthrough into domestic prices. In the long-run and based on equation 9, nominal bilateral exchange rate and symmetric oil price shocks are responsible for the major changes in domestic prices. The results obtained are in line with the findings of Maka (2013), B Imimole (2011), Bada et al. (2016), Jobarteha and Yeboua (2016) and Omoniyi and Olawale (2015). The ARDL approach to exchange rate pass-through to inflation revealed a new results and experience that cannot be obtained in applying other traditional methodological approaches. Government can with efforts control domestic inflation by controlling major outside sources. Indirect impacts of pegging on domestic inflation could be studied and reviewed in light of variations in the US dollar.

\section{Research Limitations}

This research is carried out despite some limitations. Data on some of the variables are not complete. The lack of historical data such as interest rate compelled researcher to ignore it. Further development of this paper will serve achieving concrete results by adding and testing new additional and relevant variables such as aggregate supply and trade openness...etc.

\section{Acknowledgement}

This research is supported financially by Deanship of graduate studies and scientific research at Dar Al-Uloom University at Riyadh, Saudi Arabia. Their support is highly appreciated.

\section{Contribuition}

This work is solely mine. An eclectic model is developed based on McCarthy (2000) with some modifications to fit the Saudi data.

\section{Ethics}

This article is original. The author tested exchange rate pass-through into inflation using ARDL approach for Saudi Arabia. Hence, no ethical issues involved, nor conflict of interest.

\section{References}

Abdurehman, A. and S. Hacilar, 2016. The relationship between exchange rate and inflation: An empirical study of Turkey. Int. J. Econom. Financial Issues, 6: 1454-1459.

Alkhareif, R., A. Albakr and S. Alsayaary, 2016. Exchange rate pass-through in Saudi Arabia. Saudi Arabian Monetary Authority (SAMA) Working Paper: WP/16/2.

Abimbola, O. and M. Babatunde, 2009. A bound testing analysis of exchange rate pass-through to aggregate import prices in Nigeria: 1980-2006. J. Economic Dev., 34: 97-109. 
Auda, N. and M. Amaegberi, 2013. Exchange rate fluctuation and inflation targeting in an open economy: Econometric approach. Eur. J. Account. Audit. Finance Res., 1: 24-42.

Bada, A., A. Oulfemi, I. Tata, I. Peters and S. Bawa et al., 2016. Exchange rate pass-through to inflation in Nigeria. CBN J. Applied Stat., 7: 49-70.

B Imimole, A., 2011. Exchange rate depreciation and inflation in Nigeria: 1986-2008. Bus. Economic J., 2011: 1-12.

Ca'Zorzi, M., E. Hahn and M. Sánchez, 2007. Exchange rate pass-through in emerging markets. European Central Bank Working Paper Series No. 739.

Cheikh, N. and C. Rault, 2015. Recent estimates of exchange rate pass-through to import prices in the euro area. CESifo working paper No. 5341.

Choudhri, E. and M. Khan, 2002. The exchange rate and consumer prices in Pakistan: Is rupee devaluation inflationary? Pak. Dev. Rev., 41: 107-120.

Comunale, M. and D. Kunovac, 2017. Exchange rate pass-through in euro area. European Central Bank working paper series, No. 2003.

Ebiringa, O. and N. Anyaogu, 2014. Exchange rate, inflation and interest rates relationships: An autoregressive distributed lags analysis. J. Econom. Dev. Stud., 2: 263-279.

Edwards, S., 1989. Exchange controls, devaluation and real exchange rates: The Latin American experience. Economic Dev. Cultural Change, 37: 457-494.

Edwards, S., 2006. The relationship between exchange rates and inflation targeting revisited. NBER working paper 12163 .

Fareed, Z., B. Zulfiqar, F. Shahzad and H. Husain, 2017. Exchange rate overshooting and its impact on balance of trade: A case of Pakistan. Eur. Acad. Res., 5: 1405-1420.

Faruqee, H., 2004. Exchange rate pass-through in the euro area: The role of asymmetric pricing behavior. IMF working paper WP/04/14.

Forero, F. and M. Vega, 2016. Asymmetric exchange rate pass-through: Evidence from nonlinear SVARs. Peruvian Economic Association Working Paper, No. 63.

Hüfner, F. and M. Schröder, 2002. Exchange rate passthrough to consumer prices: A European perspective. Center for European Economic Research (ZEW) discussion paper No. 02-20.
Jobarteha, M. and K. Yeboua, 2016. Exchange rate passthrough and consumer prices: Empirical evidence from the Gambia. Int. J. Econom. Commerce Manage., 4: 16-26.

Khan, A., Q. Masood and K. Hyder, 2009. Determinants of recent inflation in Pakistan. MPRA Paper No. 16254.

Lariau, A., M. El Said and M. Takebe, 2016. An assessment of the exchange rate pass-through in Angola and Nigeria. IMF Working Paper, WP/16/191.

McCarthy, J., 2000. Pass-through of exchange rates and import prices to domestic inflation in some industrialized economies. BIS Working Paper 79, Bank of International Settlements.

Maka, E., 2013. Asymmetric pass-through of exchange rate changes to CPI inflation in Ghana. Int. J. Econom. Commerce Manage., 2: 338-350.

Mirdala, R., 2014. Exchange rate pass-through to consumer prices in the European transition economies. Proceedings of the Enterprise and Competitive Environment Conference, Mar. 6-7, Brno, Czech Republic.

Morosan, G. and I. Zubas, 2015. Interest rate, exchange rate and inflation in Romania: Correlates and interconnection. J. Public Admin. Finance Law, 8: 146-160.

Nkro, E. and A.K. Uko, 2016. Autoregressive Distributed Lag (ARDL) co-integration technique: Application and interpretation. J. Stat. Econometric Meth., 5: 63-91.

Omoniyi, L. and A. Olawale, 2015. An application of ARDL bounds testing procedure to the estimation of level relationship between exchange rate, crude oil prices and inflation rate in Nigeria. Int. J. Stat. Applic., 5: 81-90.

DOI: $10.5923 /$ j.statistics.20150502.06

Omotor, D., 2008. Exchange rate reform and its inflationary consequences: The case of Nigeria. Ekonomski Pregled, 59: 688-716.

Pesaran, M., Y. Shin and R. Smith, 2001. Bounds testing approaches to the analysis of level relationships. J. Applied Econometr., 16: 289-326.

Ude, D. and U. Anochie, 2014. Exchange rate passthrough, monetary policy and price stability in Nigeria. Int. J. Sci. Res., 3: 1082-1087. 